\title{
ETIKA UANG, RELIGIUSTAS, DAN PENGGELAPAN PAJAK
}

\author{
Shafira Dwi Ollyviani \\ savira.dwioliviani@gmail.com \\ Program Studi Akuntansi, Universitas Ahmad Dahlan \\ Amir Hidayatulloh \\ amir.hidayatulloh@act.uad.ac.id \\ Program Studi Akuntansi, Universitas Ahmad Dahlan
}

\begin{abstract}
Abstrak
Penelitian ini bertujuan untuk mengetahui pengaruh etika uang, religiusitas intrinsik, dan religiusitas ekstrinsik terhadap penggelapan pajak. Populasi penelitian ini yaitu wajib pajak orang pribadi di Daerah Istimewa Yogyakarta. Teknik pengambilan sampel penelitian ini menggunakan purposive sampling dengan kriteria wajib pajak orang pribadi yang berada di Kabupaten Bantul dan memiliki Nomor Pokok Wajib Pajak. Pengumpulan data menggunakan kuesioner yang disebarkan secara langsung kepada responden yang memenuhi kriteria. Responden berjumlah 105 responden yang terdiri dari 64 responden berjenis kelamin perempuan dan 41 responden berjenis kelamin laki-laki. Analisis data dilakukan dengan menggunakan regresi linear berganda. Hasil yang diperoleh penelitian ini yaitu etika uang, religiusitas baik intrinsik maupun ekstrinsik merupakan faktor yang memengaruhi penggelapan pajak. Penelitian ini diharapkan dapat memberikan implikasi baik secara teori maupun secara praktik. Dari sisi teori, penelitian ini diharapkan dapat memperluas penelitian di bidang perpajakan, sedangkan dari sisi praktik penelitian ini diharapkan dapat memberikan informasi kepada Direktorat Jenderal Pajak mengenai faktor yang mendorong wajib pajak untuk melakukan penggelapan, sehingga Direktorat Jenderal Pajak dapat menggunakan informasi ini dalam membuat suatu kebijakan.
\end{abstract}

Kata Kunci : Penggelapan Pajak, Etika Uang, religiusitas Intrinsik, Religiusitas Ekstrinsik

\section{Abstract}

This study aims to determine the effect of money ethics, intrinsic religiosity, and extrinsic religiosity on tax evasion. The population of this study is individual taxpayers in the Special Region of Yogyakarta. The sampling technique of this study used purposive sampling with the criteria of individual taxpayers residing in Bantul Regency and having a Taxpayer Identification Number. Collecting data using a questionnaire that is distributed directly to respondents who meet the criteria. The respondents were 105 respondents consisting of 64 female respondents and 41 male respondents. Data analysis was performed using multiple linear regression. The results obtained by this study are money ethics, both intrinsic and extrinsic religiosity are factors that influence tax evasion. This research is expected to provide implications both in theory and practice. Form a theoretical perspective, this research is expected to be able expand research in the field of taxation,while in term of practice this research is expected to provide information to Directorate General of Taxes regarding the factors that encourage taxpayers to commit tae evasion, so that the Directorate General of Taxes can use this information in making policy.

Keywords: tax evasion, money ethics, intrinsic religiosity, extrinsic religiosity 


\section{PENDAHULUAN}

Sampai saat ini, pajak masih menjadi sumber andalan penerima negara. Selama dua tahun teakhir (tahun 2018 sampai dengan tahun 2020), tujuh puluh persen penerimaan negara berasal dari sektor pajak (Badan Pusat Statistik, 2021). Akan tetapi, tingkat penerimaan negara yang berasal dari sektor pajak berbeda-beda, termasuk salah satunya Daerah Istimewa Yogyakarta (DIY). Propinsi DIY memiliki lima Kabupaten/Kota, dan setiap Kabupaten/Kota memiliki realisasi penerimaan pajak yang berbeda-beda. Berdasarkan data penerimaan kantor pajak Direktorat Jenderal Pajak, persentase penerimaan pajak di DIY mencapai 81,27\%. Hal ini mengindikasikan bahwa tingkat kepatuhan wajib pajak di DIY tergolong sangat tinggi, akan tetapi target penerimaan pajak di Kabupaten/Kota tersebut masih tergolong rendah. Dari lima Kabupaten/Kota yang berada di DIY, kabupaten Gunungkidul adalah kabupaten yang memiliki persentase penerimaan pajak serta pertumbuhan yang rendah. Hal ini ditunjukan dari data penerimaan pajak masing-masing Kabupaten/Kota di DIY. Data tersebut disajikan pada tabel 1.

Tabel 1. Penerimaan Pajak di Daerah Istimewa Yogyakarta

\begin{tabular}{clcc}
\hline No & Kabupaten/Kota & $\begin{array}{c}\text { Penerimaan } \\
\text { Pajak (\%) }\end{array}$ & $\begin{array}{c}\text { Tingkat Pertumbuhan } \\
(\mathbf{\%})\end{array}$ \\
\hline 1. & Bantul & $85,27 \%$ & $22,83 \%$ \\
\hline 2. & Sleman & $82,08 \%$ & $16,74 \%$ \\
\hline 3. & Yogyakarta & $80,87 \%$ & $11 \%$ \\
\hline 4. & Kulonprogo & $75,47 \%$ & $11 \%$ \\
\hline 5. & Gunungkidul & $67,22 \%$ & $8,32 \%$ \\
\hline
\end{tabular}

Sumber: (Hapsari, 2018)

Tabel 1 menunjukan bahwa kabupaten yang Bantul merupakan kabupaten yang memiliki tingkat penerimaan pajak terbesar di bandingkan Kabupaten/Kota lain di DIY, yaitu sebesar 85,27 persen. Begitu juga dengan tingkat pertumbuhannya kabupaten Bantul merupakan kabupaten yang memiliki tingkat pertumbuhan paling tinggi dibandingkan dengan Kabupaten/Kota di DIY yaitu sebesar 22,83 persen. Sedangkan, Kabupaten Gunung Kidul merupakan kabupaten yang memiliki tingkat baik dari sisi penerimaan pajak $(67,22$ persen) dan tingkat pertumbuhan (8,32 persen) terendah dibandingkan dengan Kabupaten/Kota di DIY. Oleh karena itu, dari data yang disajikan pada tabel 1 mengindikasikan bahwa wajib pajak di Kabupaten Bantul memiliki niat untuk menggelapan pajak relatif lebih rendah dibandingkan dengan Kabupaten/Kota lain yang ada di Daerah Istimewa Yogyakarta.

Beberapa penelitian terdahulu sudah meneliti mengenai faktor yang memengaruhi perilaku tidak etis, termasuk didalamnya perilaku penggelapan pajak. Seperti (Nurachmi \& Hidayatulloh, 2021); (Abdurahman \& Hidayatulloh, 2020); (Nugroho et al., 2020); (Mutingatun \& Hidayatulloh, 2020); (Ganinda et al., 2020); (Hafizhah, 2016) yang menyatakan bahwa salah satu faktor yang memengaruhi penggelapan pajak adalah etika uang. Selain itu, (Hidayatulloh \& Syamsu, 2020); (Sofha \& Utomo, 2018) juga mengungkapkan bahwa faktor lain yang memengaruhi penggelapan pajak adalah religiusitas. Dari hasil penelitian sebelumnya, maka penelitian ini mencoba ingin menguji pengaruh etika dan religiusitas terhadap penggelapan pajak. Akan tetapi, penelitian ini membagi religiustas menjadi dua yaitu religiusitas intrinsik dan religiusitas ekstrinsik. Hal ini sesuai dengan pernyataan (Allport \& Ross, 1967) yang membagi religiusitas menjadi dua yaitu religiusitas intrinsik dan religiusitas ektrinsik.

Seseorang wajib pajak yang memiliki rasa kecenderungan mencintai uang, memiliki perilaku yang cenderung tidak mau mengeluarkan uangnya untuk kegiatan yang dianggap tidak penting baginya serta kegiatan yang dianggap tidak memberikan timbal balik kepadanya. Oleh karena itu, wajib pajak beranggapan bahwa perilaku membayar pajak akan 
mengurangi uang yang dimilikinya (Hafizhah, 2016). Selain itu, keyakinan agama sebagai salah satu cara mencegah perilaku buruk (Grasmick et al., 1991). Menurut (Allport \& Ross, 1967), religiusitas dibagi menjadi dua yaitu religiusitas intrinsik dan religiusitas ekstrinsik.

Dalam pandangan agama, perilaku untuk menggelapan pajak adalah salah satu perilaku yang tidak beretika. Sehingga, wajib pajak yang memiliki sikap religiusitas cenderung untuk menghindari perilaku tersebut karena perilaku penggelapan pajak dianggap perilaku tidak etis (Hafizhah, 2016); (Syamsu \& Hidayatulloh, 2021); (Hidayatulloh \& Syamsu, 2020); (Singhapakdi et al., 2013). Dari uraian sebelumnya, maka tujuan penelitian ini adalah untuk menganalisis pengaruh etika uang, religiusitas intrinsik, religiusitas ekstrinsik terhadap penggelapan pajak.

\section{Kajian Teori}

\section{Penggelapan Pajak}

Menurut (Mardiasmo, 2016), pemerintah menghadapi dua hambatan dalam melakukan pemungutan pajak yaitu penghindaran pajak dan penggelapan pajak. Penggelapan pajak merupakan tindakan illegal yang bertujuan untuk memperkecil bahkan kalau bisa tidak membayarkan pajaknya sesuai dengan ketentuan yang berlaku, misalnya tidak dapat memenuhi pelaporan penghasilan serta tidak tepat waktu dalam melaporkan pajaknya. Sedangkan, penghindaran pajak merupakan suatu perilaku yang bertujuan memperkecil pajak yang dibayarkan akan tetapi tidak melanggar undang-undang.

\section{Etika Uang}

Uang adalah salah satu yang dapat menentukan kepribadian Individu (Mitchell \& Mickel, 1999). Individu yang memiliki rasa cinta uang yang besar akan memiliki kecenderungan untuk tidak mau mengeluarkan uangnya karena individu tersebut beranggapkan bahwa tidak ada timbal balik yang akan diterima. Sementara, pajak merupakan suatu pungutan yang dapat bersifat dipaksa, sehingga individu tersebut berupatan untuk menghindari pembayaran pajak (Hafizhah, 2016).

\section{Religiusitas}

Menurut (McDaniel \& Burnett, 1990), keyakinan individu pada agama menjadi pedoman individu dalam melaksanakan kehidupannya. Sehingga, individu yang memiliki religiusitas tinggi memiliki kemampuan untuk mengendalikan dirinya dari perilaku yang tidak etis. Menurut (Allport \& Ross, 1967), religiuistas terdiri dari religiuistas intrinsik dan religiusitas ekstrinsik.

Religiusitas intrinsik merupakan keyakinan individu untuk memeluk agama serta melaksanakannya dengan sungguh-sungguh (Allport \& Ross, 1967). Individu yang memiliki religiusitas intrinsik memiliki karakter bahwa agama merupakan bagian dari kehidupan sehari-harinya. Oleh karena itu, individu tersebut akan menjadikan agama sebagai pedoman hidup, hidup bermoral secara konsisten, dan memiliki rasa tanggung jawab kepada Tuhan, manusia, serta selalu mencari kebenaran (Ismail, 2012).

Religiusitas ekstrinsik merupakan partisipasi individu guna mencapai tujuan beragama (Allport \& Ross, 1967). Individu yang memiliki karakter religiusitas ekstrinsik merupakan individu yang menggunakan agama sebagai dukungan sosial bahkan kepuasan individu semata. Oleh karena itu, individu yang memiliki karakter religiusitas ekstrinsik mungkin rajin melaksanakan ibadah dan memiliki kecenderungan yang besar dalam menggunakan religiusitasnya guna mencapai kepentingan pribadi (Suminta, 2017). 


\section{Pengembangan Hipotesis}

\section{Pengaruh Etika Uang Terhadap Penggelapan Pajak}

Uang merupakan alat satuan pengukur yang digunakan individu untuk mendapatkan barang atau jasa. Uang dapat menentukan kepribadian dan sikap individu mengenai seberapa penting uang bagi individu tersebut (Mitchell \& Mickel, 1999). Sehingga, individu yang mencintai uangnya sangat besar cenderung tidak mau mengeluarkan uangnya untuk kegiatan yang dianggapnya tidak penting dan tidak memberikan timbal balik baginya. Sehingga, cinta uang merupakan salah satu penyebab wajib pajak untuk melakukan penggelapan pajak. Pernyataan ini didukung oleh beberapa hasil penelitian sebelumnya, seperti (Nurachmi \& Hidayatulloh, 2021); (Abdurahman \& Hidayatulloh, 2020); (Nugroho et al., 2020); (Mutingatun \& Hidayatulloh, 2020); (Ganinda et al., 2020); (Hafizhah, 2016) yang menyatakan bahwa cinta uang merupakan salah satu faktor yang berpengaruh terhadap perilaku tidak etis, termasuk didalamnya perilaku penggelapan pajak. Dengan demikian, hipotesis pertama (H1) penelitian ini adalah sebagai berikut.

H1: Etika uang berpengaruh terhadap penggelapan pajak

\section{Pengaruh Religiusitas Intrinsik terhadap Penggelapan Pajak}

Keyakinan yang dianut oleh individu merupakan salah satu yang menentukan penilaian individu terhadap perilaku, apakah termasuk perilaku etis maupun tidak etis. Sehingga, perilaku individu akan dipengaruhi oleh komitmen agama yang dianutnya (Rosianti \& Mangoting, 2014). Berdasarkan perpektif agama, perilaku penggelapan pajak merupakan perbuatan yang tidak beretika. Oleh karena itu, wajib pajak yang berorientasi religiusitas intrinsik beranggapan bahwa penggelapan pajak adalah perilaku tidak etis walaupun dengan alasan apapun. Wajib pajak yang memiliki keyakinan agama yang kuat diharapkan mampu menghindari perilaku illegal melalui perasaan bersalah ketika saat melakukan perbuatan tersebut. Sehingga, wajib pajak beranggapan bahwa kewajiban pajak harus segera dipenuhi karena untuk kesejahteraan masyarakat baik masyarakat yang mampu maupun masyarakat yang tidak mampu karena penerimaan pajak yang digunakan oleh pemerintah untuk kepentingan umum, seperti membangun infrastruktur, beasiswa, pendidikan dan lan sebagainya. Individu yang memiliki religiusitas tinggi memiliki kecenderungan untuk berpenampilan sederhan dan taat pada agamanya serta aturan yang berlaku di Indonesia. Hal ini didukung oleh hasil beberapa hasil penelitian sebelumnya seperti (Hafizhah, 2016); (Syamsu \& Hidayatulloh, 2021); (Hidayatulloh \& Syamsu, 2020); (Singhapakdi et al., 2013) yang menyatakan bahwa religiuistas berpengaruh terhadap penggelapan pajak. Dengan demikian, hipotesis kedua $(\mathrm{H} 2)$ penelitian ini adalah sebagai berikut.

$\mathrm{H} 2$ : Religiusitas intrinsik berpengaruh terhadap penggelapan pajak

\section{Religiusitas Ekstrinsik Berpengaruh Terhadap Penggelapan Pajak}

Religiusitas ekstrinsik merupakan perbuatan yang dilakukan individu guna memanfaatkan agama sebagai alat dalam kehidupan sehari-hari dan memenuhi kebutuhan pribadinya. Sehingga, individu tersebut akan lebih termotivasi jika ada sesuatu yang menguntungkan dalam hal duniawi (Allport \& Ross, 1967). Sehingga, semakin rendah tingkat religiusitas yang dimiliki wajib pajak, maka semakin besar kemungkinan untuk melakukan 
penggelapan pajak (Hidayatulloh \& Syamsu, 2020); (Singhapakdi et al., 2013). Oleh karena itu, hipotesis ketiga (H3) penelitian ini adalah sebagai berikut:

H3: Religiusitas ekstrinsik berpengaruh terhadap penggelapan pajak

Dari uraian pengembangan hipotesis, maka rerangka penelitian ini adalah sebagai berikut:

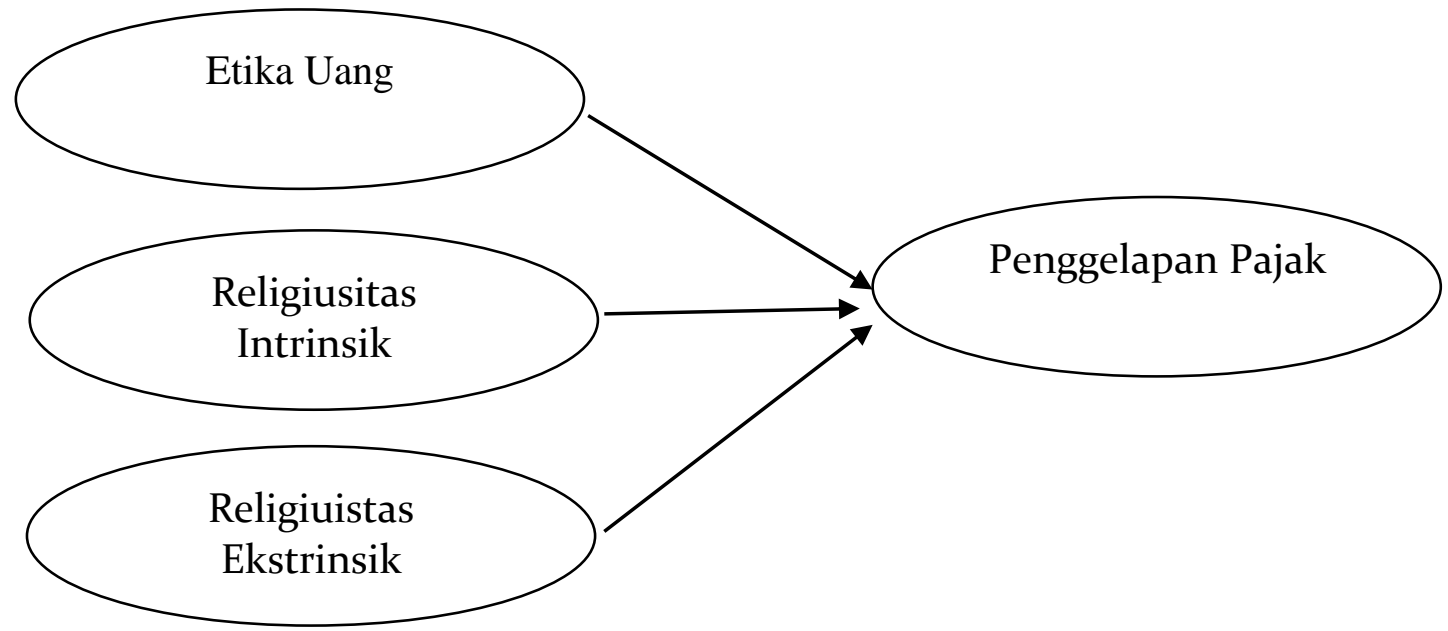

Gambar 1. Rerangka Penelitian

\section{METODE}

Populasi penelitian ini adalah wajib pajak orang pribadi (WPOP) di Daerah Istimewa Yogyakarta, sedangkan sampel penelitian ini adalah wajib pajak orang pribadi yang berada di Kabupaten Bantul. Teknik pengambilan sampel menggunakan purposive sampling, dengan kriteria wajib pajak orang pribadi yang memiliki Nomor Pokok Wajib Pajak (NPWP). Variabel penelitian ini terdiri dari variabel independen (etika uang, religiusitas intrinsik, dan religiusitas ekstrinsik), dan variabel dependen (penggelapan pajak). Definisi operasional dan pengukuran masing-masing variabel disajikan pada tabel 2.

Tabel 2. Definisi Operasional dan Pengukuran Variabel

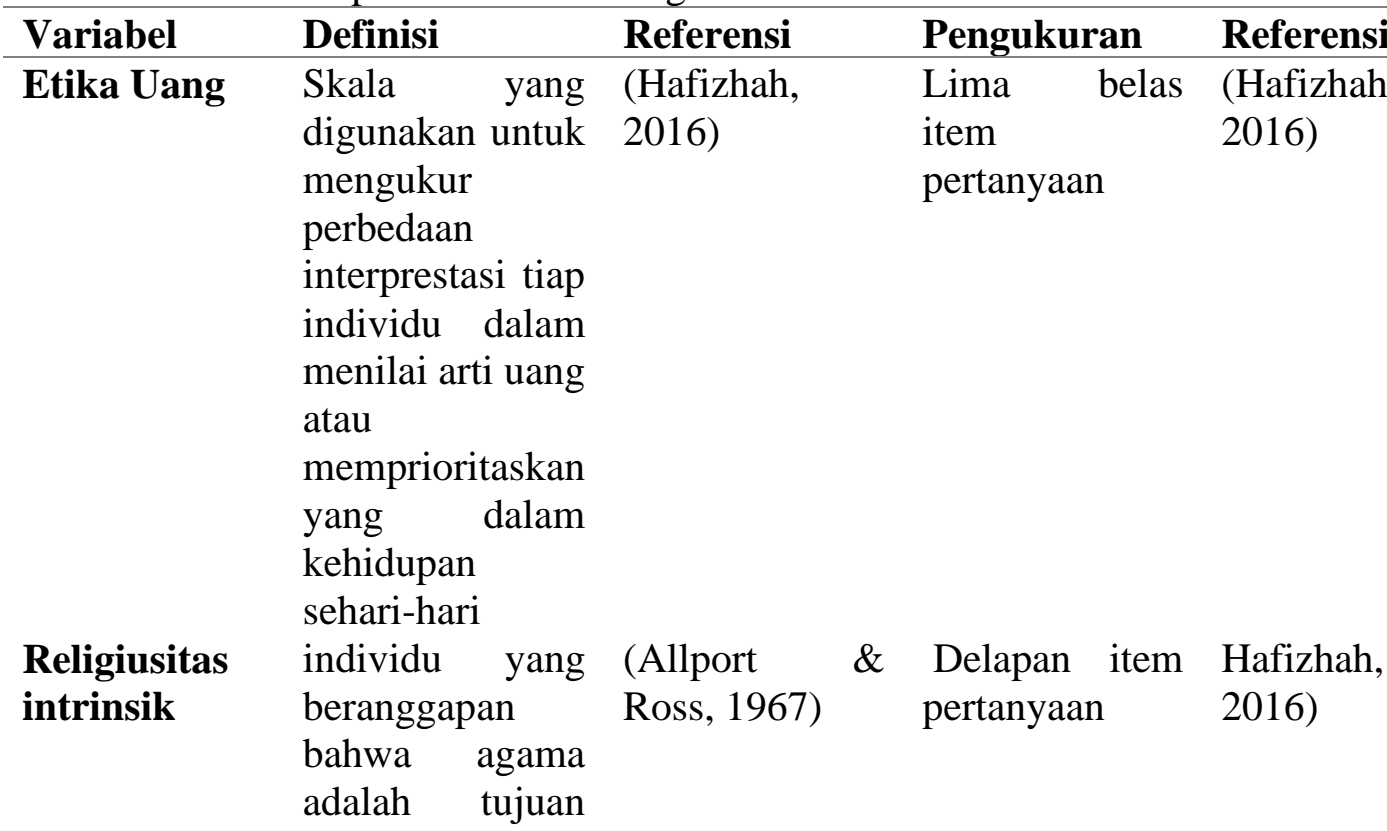




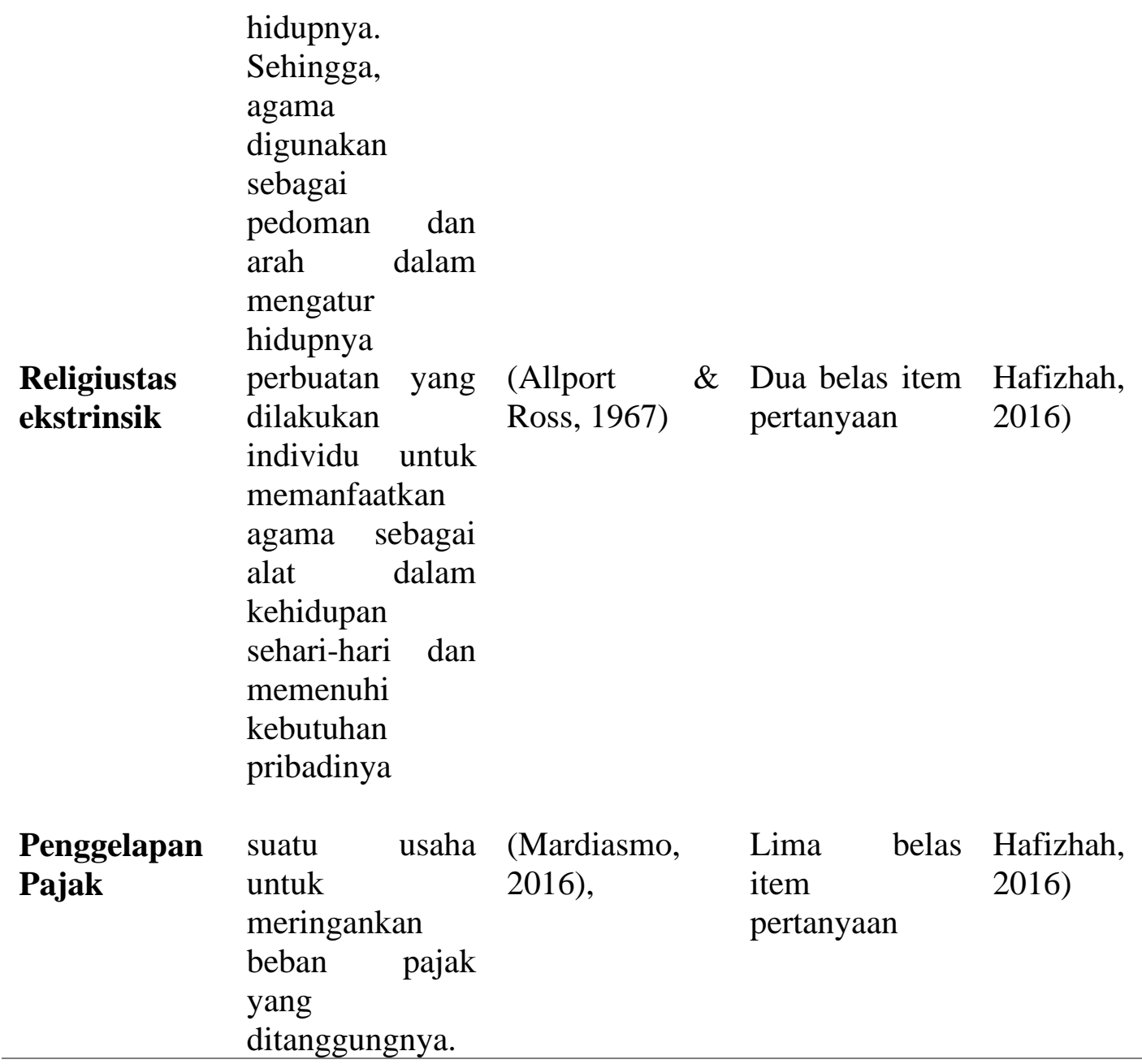

Masing-masing variabel diukur dengan menggunakan skala likert lima poin. Penelitian ini menggunakan teknik analisis regresi linear berganda dengan bantuan SPSS.

\section{HASIL DAN PEMBAHASAN}

Responden penelitian ini berjumlah 105 yang terdiri dari 64 responden berjenis kelamin perempuan dan 41 responden berjenis kelamin laki-laki. Responden penelitian didominasi oleh usia diatas 45 tahun yaitu sebanyak 51 responden. Tingkat pendidikan responden terdiri dari sekolah menengah atas, diploma, dan sarjana. Akan tetapi, tingkat pendidikan responden didominasi oleh tingkat pendidikan sarjana yaitu sebanyak 81 responden. Data rinci mengenai usia dan tingkat pendidikan responden disajikan pada tabel 3.

Tabel 3. Deskripsi Responden

\begin{tabular}{lc}
\hline \multicolumn{1}{c}{ Deskripsi Responden } & Jumlah \\
\hline Usia (Tahun) & \\
\hline $\mathbf{2 0 - 2 5}$ & 6 \\
$\mathbf{2 6 - 3 0}$ & 9 \\
$\mathbf{3 1 - 3 5}$ & 14 \\
$\mathbf{3 6 - 4 0}$ & 11 \\
$\mathbf{4 1 - 4 5}$ & 14
\end{tabular}


Diatas 45

Pendidikan Terakhir

SMA

6

D1/D2/D3

18

S1/S2/S3

81

Sumber: data diolah, (2020)

Analisis data yang digunakan penelitian ini adalah analisis regresi linear berganda. Sebelum melakukan pengujian hipotesis, penelitian ini terlebih dahulu melakukan uji kualitas data dan asumsi klasik. Hasil uji validitas dan uji reliabilitas disajikan pada tabel 4 dan tabel 5 .

Tabel 4. Hasil Uji Validitas

\begin{tabular}{|c|c|c|c|}
\hline $\begin{array}{c}\text { Item } \\
\text { Pernyata }\end{array}$ & r Hitung & r Tabel & Kesimpulan \\
\hline \multicolumn{4}{|c|}{ Penggelapan Pajak } \\
\hline 1 & 0,607 & 0,192 & Valid \\
\hline 2 & 0,341 & 0,192 & Valid \\
\hline 3 & 0,502 & 0,192 & Valid \\
\hline 4 & 0,534 & 0,192 & Valid \\
\hline 5 & 0,453 & 0,192 & Valid \\
\hline 6 & 0,473 & 0,192 & Valid \\
\hline 7 & 0,512 & 0,192 & Valid \\
\hline 8 & 0,201 & 0,192 & Valid \\
\hline 9 & 0,567 & 0,192 & Valid \\
\hline 10 & 0,292 & 0,192 & Valid \\
\hline 11 & 0,643 & 0,192 & Valid \\
\hline 12 & 0,614 & 0,192 & Valid \\
\hline 13 & 0,429 & 0,192 & Valid \\
\hline 14 & 0,291 & 0,192 & Valid \\
\hline 15 & 0,361 & 0,192 & Valid \\
\hline \multicolumn{4}{|c|}{ Etika Uang } \\
\hline 1 & 0,656 & 0,192 & Valid \\
\hline 2 & 0,629 & 0,192 & Valid \\
\hline 3 & 0,648 & 0,192 & Valid \\
\hline 4 & 0,581 & 0,192 & Valid \\
\hline 5 & 0,515 & 0,192 & Valid \\
\hline 6 & 0,454 & 0,192 & Valid \\
\hline 7 & 0,466 & 0,192 & Valid \\
\hline 8 & 0,580 & 0,192 & Valid \\
\hline 9 & 0,585 & 0,192 & Valid \\
\hline 10 & 0,614 & 0,192 & Valid \\
\hline
\end{tabular}




$\begin{array}{llll}\mathbf{1 1} & 0,610 & 0,192 & \text { Valid } \\ \mathbf{1 2} & 0,501 & 0,192 & \text { Valid } \\ \mathbf{1 3} & 0,475 & 0,192 & \text { Valid } \\ \mathbf{1 4} & 0,250 & 0,192 & \text { Valid } \\ \mathbf{1 5} & 0,224 & 0,192 & \text { Valid }\end{array}$

\section{Religiusitas Intrinsik}

$\begin{array}{llll}\mathbf{1} & 0,563 & 0,192 & \text { Valid } \\ \mathbf{2} & 0,758 & 0,192 & \text { Valid } \\ \mathbf{3} & 0,758 & 0,192 & \text { Valid } \\ \mathbf{4} & 0,402 & 0,192 & \text { Valid } \\ \mathbf{5} & 0,375 & 0,192 & \text { Valid } \\ \mathbf{6} & 0,649 & 0,192 & \text { Valid } \\ \mathbf{7} & 0,726 & 0,192 & \text { Valid } \\ \mathbf{8} & 0,684 & 0,192 & \text { Valid }\end{array}$

\section{Religiusitas Ekstrinsik}

$\begin{array}{cccc}\mathbf{1} & 0,549 & 0,192 & \text { Valid } \\ \mathbf{2} & 0,497 & 0,192 & \text { Valid } \\ \mathbf{3} & 0,582 & 0,192 & \text { Valid } \\ \mathbf{4} & 0,522 & 0,192 & \text { Valid } \\ \mathbf{5} & 0,528 & 0,192 & \text { Valid } \\ \mathbf{6} & 0,351 & 0,192 & \text { Valid } \\ \mathbf{7} & 0,528 & 0,192 & \text { Valid } \\ \mathbf{8} & 0,636 & 0,192 & \text { Valid } \\ \mathbf{9} & 0,645 & 0,192 & \text { Valid } \\ \mathbf{1 0} & 0,537 & 0,192 & \text { Valid } \\ \mathbf{1 1} & 0,277 & 0,192 & \text { Valid } \\ \mathbf{1 2} & 0,283 & 0,192 & \text { Valid }\end{array}$

Tabel 4 menunjukan bahwa semua indikator memiliki nilai $r$ hitung yang lebih besar dibandingkan dengan $r$ tabel. Sehingga, dapat disimpulkan bahwa semua indikator yang digunakan dalam penelitian ini valid.

Tabel 5. Uji Realibilitas

\begin{tabular}{cccc}
\hline Variabel & Cronbach Alpha & Nilai Cut Off & Keterangan \\
\hline Penggelapan Pajak & 0,723 & 0,70 & Reliabel \\
Etika Uang & 0,802 & 0,70 & Reliabel \\
Religiusitas Intrinsik & 0,776 & 0,70 & Reliabel \\
Religiusitas Ekstrinsik & 0,701 & 0,0 & Reliabel \\
\hline
\end{tabular}

Tabel 5 menunjukan bahwa nilai Cronbach alpha pada masing-masing variabel diatas 0,7. Sehingga, dapat disimpulkan bahwa instrumen yang digunakan dalam penelitian reliabel. 
Selain uji kualitas data, penelitian ini juga melakukan uji asumsi klasik yang terdiri dari uji normalitas, uji multikolinearitas, dan uji heteroskedastisitas. Hasil pengujian asumsi klasik disajikan pada tabel 6, tabel 7, dan tabel 8.

Tabel 6. Hasil Uji Normalitas

Unstandardized Residual

Normal Parameters ${ }^{\mathrm{a}, \mathrm{b}}$

Mean

.0000000

Std. Deviation

6.39777893

Most Extreme Differences

Absolute

.080

Positive

.080

Negative

Kolmogorov-Smirnov

.824

Asymp. Sig. (2-tailed)

.506

Tabel 6 menunjukan bahwa nilai asymp sig (2-tailed) menunjukan nilai signifikasi 0,506 yang lebih besar dibandingkan dengan 0,5. Sehingga, penelitian ini memenuhi uji normalitas atau dengan kata lain residual data dalam penelitian ini berdistribusi normal.

Tabel 7. Hasil Uji Multikolinearitas

\begin{tabular}{cccl}
\hline Variabel Independen & Tolerance & VIF & Keterangan \\
\hline EtikaUang & 0,997 & 1,003 & Tidak terjadi multikolinearitas \\
Religiusitas Intrinsik & 0,864 & 1,157 & Tidak terjadi multikolinearitas \\
Religiusitas Ekstrinsik & 0,867 & 1,154 & Tidak terjadi multikolinearitas
\end{tabular}

Tabel 7 menunjukan bahwa masing-masing variabel independent memiliki nilai tolerance yang lebih besar dari 0,10 dan nilai VIF lebih kecil dari 10. Oleh karena itu, penelitian ini tidak terjadi multikolineraritas pada variabel independent.

Tabel 8. Hasil Uji Heteroskesdastisitas

\begin{tabular}{ccc}
\hline Variabel Independen & Signifikansi & Keterangan \\
\hline Etika Uang & 0,200 & Tidak terjadi heteroskedastisitas \\
Religiusitas Intrinsik & 0,163 & Tidak terjadi heteroskedastisitas \\
Religiusitas Ekstrinsik & 0,446 & Tidak terjadi heteroskedastisitas \\
\hline
\end{tabular}

Tabel 8 menunjukan bahwa nilai signifikasi masing-masing variabel diatas 0,05 . Oleh karena itu, penelitian ini memenuhi uji heteroskesdastisitas.

Setelah penelitian ini memenuhi uji kualitas data dan uji asumsi klasik maka tahap selanjutnya yang dilakukan adalah pengujian hipotesis. Hasil pengujian hipotesis disajikan pada tabel 9. 
Tabel 9. Hasil Pengujian Hipotesis

\begin{tabular}{lcccc}
\hline \multicolumn{1}{c}{ Variabel } & Koefisien & Signifikansi & Alpha & Keputusan \\
\hline Etika Uang & 0,073 & 0,003 & 0,05 & H1 Terdukung \\
Religiusitas & 0,130 & 0,001 & 0,05 & H2 Terdukung \\
$\begin{array}{l}\text { Intrinsik } \\
\text { Religiusitas }\end{array}$ & 0,099 & 0,000 & 0,05 & H3 Terdukung \\
Ekstrinsik & & & & \\
Konstanta & $=18,352$ & & & \\
Variabel dependen & $=$ Penggelapan Pajak & & \\
Adjusted R Square & $=0,203$ & & \\
F Statistik & $=9,849$ & & & \\
Signifikansi & $=0,000$ & & &
\end{tabular}

Sumber: data diolah (2020)

Tabel 9 menunjukan bahwa faktor yang memengaruhi wajib pajak orang pribadi untuk melakukan perilaku penggelapan pajak antara lain etika uang, religiuistas baik religiusitas intrinsik maupun esktrinsik. Hal ini terlihat dari hasil uji t yang masing-masing variabel memiliki nilai signifikasi kurang dari 0,05. Atau dengan kata lain, hipotesis pertama, kedua, dan ketiga $(\mathrm{H} 1, \mathrm{H} 2$, dan $\mathrm{H} 3)$ terdukung. Hal ini berarti bahwa individu yang memiliki rasa cinta uang cenderung enggan untuk mengeluarkan uangnya untuk kegiatan yang tidak memberikan timbal balik baginya atau kegiatan yang dianggap tidak penting baginya, seperti perilaku dalam membayar pajak. Hasil penelitian ini mendukung hasil penelitian sebelumnya (Nurachmi \& Hidayatulloh, 2021); (Abdurahman \& Hidayatulloh, 2020); (Nugroho et al., 2020); (Mutingatun \& Hidayatulloh, 2020); (Ganinda et al., 2020); (Hafizhah, 2016) yang menyatakan bahwa etika uang berpengaruh terhadap penggelapan pajak.

Selain itu, penggelapan pajak juga dipengaruhi oleh faktor religiusitas, baik religiusitas intrinsik maupun religiusitas ekstrinsik. Wajib pajak yang memiliki orientasi religiusitas intrinsik menganggap bahwa penggelapan pajak merupakan perilaku tidak etis walaupun dengan alasan apapun. Wajib pajak yang memiliki keyakinan agama yang kuat diharapkan mampu menghindari perilaku illegal melalui perasaan bersalah ketika melakukan perbuatan tersebut (Hafizhah, 2016); (Syamsu \& Hidayatulloh, 2021); (Hidayatulloh \& Syamsu, 2020); (Singhapakdi et al., 2013). Selain itu, wajib pajak berkepribadian religiusitas ekstrinsik juga akan lebih termotivasi jika ada sesuatu yang menguntungkan dirinya dalam hal duniawi (Allport \& Ross, 1967). Sehingga, semakin rendah tingkat religiusitas yang dimiliki wajib pajak, maka semakin besar kemungkinan untuk melakukan penggelapan pajak (Hidayatulloh \& Syamsu, 2020); (Singhapakdi et al., 2013).

\section{SIMPULAN}

Penelitian ini menujukan bahwa faktor yang memengaruhi wajib pajak untuk melakukan penggelapan pajak yaitu faktor etika uang, faktor religiusitas intrinsik, serta religiusitas ekstrinsik. Sehingga, wajib pajak yang memiliki cinta uang memiliki kecenderungan untuk tidak membayarkan pajaknya karena perilaku membayar pajak tidak akan memberikan timbal balik baginya. Selain itu, wajib pajak yang memiliki religiusitas yang kuat baik religiusitas intrinsik maupun religiusitas ekstrinsik diharapkan mampu menghindari perilaku penggelapan pajak.

Tidak ada penelitian yang sempurna, penelitian ini memiliki keterbatasan yaitu religiustas yang digunakan pada penelitian ini tidak spesifik mengarah pada salah satu agama yang ada di Indonesia, sehingga penelitian selanjutnya dapat menspesifikan pada satu agama, misalnya Islam, Kristen, dan lain sebagainya. 


\section{DAFTAR PUSTAKA}

Abdurahman, N. L., \& Hidayatulloh, A. (2020). Kecerdasan, Religiusitas, Kecintaan Terhadap uang dan Persepsi Etis Mahasiswa Akuntansi Universitas Ahmad Dahlan Yogyakarta. Jurnal Aplikasi Akuntansi, 4(2), 211-225.

Allport, G. W., \& Ross, J. M. (1967). Personal Religious Orientation and Prejudice. Journal of Personality and Social Psychology, 5(4), 432-443.

Badan Pusat Statistik. (2021). Realisasi Penerimaan Negara. Www.Bps.Go.Id. https://www.bps.go.id/indicator/13/1070/1/realisasi-pendapatan-negara.html

Ganinda, F. P., Fikrianoor, K., Nugroho, A. D., \& Hidayatulloh, A. (2020). Etika Uang, Religiusitas, dan Penggelapan Pajak (Studi Kasus Wajib Pajak Orang Pribadi Di Kabupaten Gunungkidul). Transparansi: Jurnal Ilmiah Ilmu Administrasi, 3(1), 39-44. https://doi.org/10.31334/transparansi.v3i1.759

Grasmick, H. G., Kinsey, K., \& Cochran, J. K. (1991). Denomination, Religiosity and Compliance with the Law: A Study of Adults. Journal for the Scientific Study of Religion, 30(1), 99. https://doi.org/10.2307/1387152

Hafizhah, I. (2016). Pengaruh Etika Uang (Money Ethics) Terhadap Kecurangan Pajak (Tax Evasion) Dengan Religiusitas,Gender dan Materialisme Sebagai Variabel Moderasi. Jurnal Online Mahasiswa (JOM) Bidang Ilmu Ekonomi, 3(1), 16521665.

Hapsari, A. (2018). Penerimaan Pajak di DIY Tumbuh 15,1 Persen. Www.Suaramerdeka.Com.

https://www.suaramerdeka.com/news/baca/154455/penerimaan-pajak-di-diytumbuh-151-persen

Hidayatulloh, A., \& Syamsu, M. N. (2020). Religiusitas Intrinsik, Religiusitas Ekstrinsik, dan Niat Untuk Menghindari Pajak. JAK (Jurnal Akuntansi): Kajian Ilmiah Akuntansi, 7(1), 44-51. https://doi.org/10.1017/CBO9781107415324.004

Ismail, R. (2012). Keberagamaan koruptor menurut psikologi. Esensia, XIII(2), 290304.

Mardiasmo. (2016). Perpajakan (2016th ed.). CV Andi.

McDaniel, S.W ., \& Burnett, J.J. (1990). Consumer Religiosity and Retail Store Evaluative Criteria. Journal of the Academy of Marketing Science, 18(2), 101-112.

Mitchell, T. R., \& Mickel, A. E. (1999). The Meaning of Money: Difference Perspective Perspective Difference. Academy of Management Review, 24(3), 568578.

Mutingatun, N., \& Hidayatulloh, A. (2020). Etika Uang Dan Kecurangan Pajak: Religiusitas Intrinsik, Religiusitas Ekstrinsik, Gender, Materialisme, Dan Cinta Uang Sebagai Variabel Moderasi. Jurnal Riset Akuntansi, 12(2), 1-15. https://doi.org/10.34010/jra.v12i2.2907

Nugroho, A. D., Ganinda, F. P., Fikrianoor, K., \& Hidayatulloh, A. (2020). Money Ethic mempengaruhi Penggelapan Pajak: Peran Love of Money. Transpransi: Jurnal Ilmiah Ilmu Administrasi, 3(2), 132-138.

Nurachmi, D. A., \& Hidayatulloh, A. (2021). Gender, Religiusitas, Love of Money, dan Etika Penggelapan Pajak. Jurnal Ilmiah Akuntansi Universitas Pamulang, 9(1), $30-41$.

Rosianti, C., \& Mangoting, Y. (2014). Pengaruh Money Ethics terhadap Tax Evasion dengan Intrinsic dan Extrinsic Religiosity sebagai Variabel Moderating. Tax \& Accounting Review, 4(1), 61. http://publication.petra.ac.id/index.php/akuntansipajak/article/view/3101 
Singhapakdi, A., Vitell, S. J., Lee, D. J., Nisius, A. M., \& Yu, G. B. (2013). The Influence of Love of Money and Religiosity on Ethical Decision-Making in Marketing. Journal of Business Ethics, 114(1), 183-191. https://doi.org/10.1007/s10551-012-1334-2

Sofha, D., \& Utomo, S. D. (2018). Keterkaitan Religiusitas, Gender, LOM Dan Persepsi Etika Penggelapan Pajak. Jurnal Ilmu Manajemen Dan Akuntansi Terapan (JIMAT, 9(2).

Suminta, R. R. (2017). Hubungan Antara Tipe Kepribadian Dengan Orentasi Religiusitas. Fikrah, 4(2), 214. https://doi.org/10.21043/fikrah.v4i2.1884

Syamsu, M. N., \& Hidayatulloh, A. (2021). Anteseden Niat Wajib Pajak Untuk Menghindari Pajak: Apakah Religiusitas Ekstrinsik, Dan Machiavellian Berperan? Jurnal Penelitian Ekonomi Dan Akuntansi, 6(1), 41-49. 